\title{
GRANULATION OF MEFENAMIC ACID AND POLY-ETHYLENE GLYCOL (PEG) USING PRESSURE SWING GRANULATION (PSG) TECHNIQUE IN FLUIDIZED BED
}

\section{(Pembentukan Granul Berasaskan Asid Mefenamik dan Polietilena Glikol (PEG) Menggunakan Teknik Pengranulan Tekanan Terayun dalam Turus Terbendalir)}

\author{
Salinda Ab Ghani ${ }^{1}$, Noor Fitrah Abu Bakar ${ }^{1} *$, Mohd Rushdi Abu Bakar ${ }^{2}$, Yus Aniza Yusof ${ }^{3}$, \\ Norazah Abd Rahman ${ }^{1}$ \\ ${ }^{I}$ Faculty of Chemical Engineering, \\ Universiti Teknologi MARA, 40450 Shah Alam, Selangor, Malaysia \\ ${ }^{2}$ Department of Pharmaceutical Technology, Kulliyyah of Pharmacy, \\ International Islamic University Malaysia, Bandar Indera Mahkota, 25200 Kuantan, Pahang, Malaysia \\ ${ }^{3}$ Department of Process and Food Engineering, Faculty of Engineering, \\ Universiti Putra Malaysia, 43400 Serdang, Selangor, Malaysia \\ *Corresponding author: fitrah@salam.uitm.edu.my
}

Received: 15 February 2017; Accepted: 2 January 2018

\begin{abstract}
Granulation of mefenamic acid particles was conducted to produce spherical shape, narrow size distribution of granules, high granule strength and good content uniformity by using Pressure Swing Granulation (PSG) technique in a fluidized bed. Two types (binderless and with binder) of granules namely lactose-mefenamic acid (MA) and lactose-polyethylene glycol (PEG)(MA) with mass ratio of 30:70 and 25:5:70 were produced respectively. The later type of granules was heated for $80{ }^{\circ} \mathrm{C}$, above the PEG melting point. Results indicated that all granules were uniform, spherical and narrow size distribution with the average granules size was less than $500 \mu \mathrm{m}$. The tensile strength of the lactose-PEG-MA was higher than the lactose-MA due to heating process. The tensile strength of lactose-PEG-MA and lactose-MA with average granules size of $500 \mu \mathrm{m}$ were $0.42 \mathrm{MPa}$ and 0.33 $\mathrm{MPa}$, respectively. The drug contents in both types of granules were uniform i.e. around $70 \pm 0.3 \mathrm{wt} . \%$.
\end{abstract}

Keywords: mefenamic acid, lactose, polyethylene glycol, pressure swing granulation

\section{Abstrak}

Pembentukan granul zarah asid mefenamik telah dijalankan untuk menghasilkan bentuk bulat, taburan saiz granul yang kecil, kekuatan granul dan keseragaman kandungan yang baik dengan menggunakan teknik pengranulan terbendalir (PSG). Dua jenis granul (tanpa perekat dan dengan perekat) iaitu laktosa-asid mefenamik (MA) dan laktosa-polietilena glikol (PEG)-(MA) dengan nisbah jisim masing-masing adalah 30:70 dan 25:5:70. Granul kemudian dipanaskan pada $80{ }^{\circ} \mathrm{C}$, melebihi takat lebur PEG. Keputusan menunjukkan bahawa semua granul yang terhasil adalah seragam, taburan saiz granul adalah sempit dengan saiz purata granul adalah kurang daripada $500 \mu \mathrm{m}$. Kekuatan tegangan laktosa-PEG-MA adalah lebih tinggi daripada laktosa-MA disebabkan oleh proses pemanasan semasa pengranulan. Kekuatan tegangan laktosa PEG-MA dan laktosa-MA dengan saiz granul purata 500 mikron masing-masing adalah $0.42 \mathrm{MPa}$ dan $0.33 \mathrm{MPa}$. Kandungan MA dalam kedua-dua jenis granul adalah seragam iaitu sekitar peratusan jisim $70 \pm 0.3 \mathrm{wt} . \%$.

Kata kunci: acid mefenamik, laktosa, polietilena glikol, pengranulan tekanan terayun 


\section{Salinda et al: GRANULATION OF MEFENAMIC ACID AND POLY-ETHYLENE GLYCOL (PEG) USING \\ PRESSURE SWING GRANULATION (PSG) TECHNIQUE IN FLUIDIZED BED}

\section{Introduction}

In the pharmaceutical industry, approximately more than $80 \%$ of all dosage forms are supplied in the forms of tablet [1]. The advantages of supplying the drugs powders in tablet form are low production cost, convenience in dosing and drug stability due to dry condition compared with liquid semi-solid presentation. Particle properties such as shape and size are important in increasing the bioavailability of active pharmaceutical ingredients (APIs). Most APIs used these days are fine powders $100 \mu \mathrm{m}$ or less which typically having a wide size distribution. Further, particles size smaller than $30 \mu \mathrm{m}$ are extremely difficult to handle and are generic problem for the industry [2].

Mefenamic acid is a non-stereoidal anti inflammatory drug (NSAIDs) that belongs to a group of fenamate medicines. Mefenamic acid is used to treat pain such as headache, dental pain and fever. It is also used to treat menstrual pain. The usual oral dosage is 250 to $500 \mathrm{mg}$, being administered three times daily [3]. Mefenamic acid works by decreases the inflammation and uterine contractions and stopping the body's production of a substance that cause pain [4]. Mefenamic acid is a poorly soluble drug in aqueous media [5], tendency to stick to surfaces and it is not easy to handle in granulation and tabletting processes.

Understanding the deformation behavior of powder under compaction or compression $[7,9,10]$ it can minimize its sticking tendency during tableting. Small/irregular particles deformed more plastically at high compression pressure and had higher tendency for friction and sticking [7]. Nano- or micrometer size range for particulate drug powders is an obstacle during manufacturing of the dosage forms containing them, particularly if the form is a conventional solid (tablet, capsule) [11]. Particle size and shape could completely change the compaction behavior of materials, which would finally affect the physical characters of the final compact (tablet) [7, 12]. Therefore, granulation is a possible method in reducing the sticking problem without changing the original size and shape of the mefenamic acid crystal.

Granulation is often added as unit operation before the compaction step to enlarge particle size and to form spherical agglomerates $[6,20]$ of the starting material but also to improve the mechanical properties under pressure $[7,8]$. Improvement of sticking tendency during tableting through granulation of APIs such as ibuprofen up to 70 wt. $\%$ with $30 \mathrm{wt} . \%$ lactose was successfully conducted through pressure swing granulation (PSG) technique in fluidized bed [6].

Thus, PSG technique can be applied for granulation of small size particles of high dosage mefenamic acid and low dosage of excipient without any binder prior to the tableting process. In this study, a binderless granulation method that is known as pressure swing granulation (PSG) technique will be used for enlarging the particle size and forming into spherical and narrow size granules prior to the tableting process.

\section{Materials and preparation of mefenamic acid}

\section{Materials and Methods}

The materials used were lactose, polyethylene glycol (PEG) and mefenamic acid (MA) powder. 5 grams of as received MA was milled by using ball mill for 60 minutes (Mixer mill, MM400) to obtain a particle size of $\sim 5 \mu \mathrm{m}$. The particle size distribution of mefenamic acid before and after milling process was measured by using a laser diffraction particle size analyzer (Malvern Mastersizer 2000).

\section{Preparation of granules}

A batch of $120 \mathrm{~g}$ of well mixed samples was fed into the PSG granulator as illustrated in Figure 1. The column was made of stainless steel consists of two part which are lower part with internal diameter of $108 \mathrm{~mm}$ and the upper part with a diameter of $151 \mathrm{~mm}$. A filter bag with a diameter of $70 \mathrm{~mm}$ and $157 \mathrm{~mm}$ in length was suspended from the top flange. Two types of granules namely lactose-MA and lactose-PEG-MA with mass ratio of 30:70 and 25:5:70 were produced respectively under operating conditions as listed in Table 1. Both types of granules were granulated for 120 minutes. 


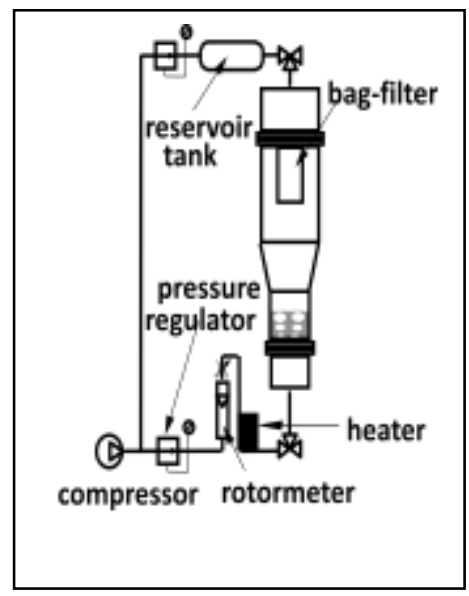

Figure 1. Experimental setup for Pressure Swing Granulation (PSG) technique [14]

Table 1. Granulation Condition

\begin{tabular}{lcc}
\hline Type of Granules & Lactose:MA & Lactose: PEG:MA \\
\hline Temperature & $25^{\circ} \mathrm{C}$ & $80^{\circ} \mathrm{C}$ \\
Powder batch mass & $120 \mathrm{~g}$ \\
Gas velocity & $0.364 \mathrm{~m} / \mathrm{s}$ \\
Duration of fluidization & $15 \mathrm{~s}$ \\
Duration of compaction & $1 \mathrm{~s}$ \\
Compaction pressure & $0.03 \mathrm{MPa}$ \\
Total granulation time & $120 \mathrm{~min}$ \\
\hline
\end{tabular}

\section{Characterization of granules}

The size distribution of the product granules was determined by using sieving method. The morphology of the granules was measured using Scanning Electron Microscopy (SEM). The density and pore volume of the granules range of 250 to $800 \mu \mathrm{m}$ were measured using pycnometer density (AccuPyc 1340, Micromeritics). Compression strength of granules was measured by using micro compression tester (Shimadzu MCT-511) for granules size range between 250 to $800 \mu \mathrm{m}$. From the measured fracture force $\left(F_{f}\right)$, the tensile strength $(\sigma)$, for brittle material can be calculated using equation from Hiramatsu and Oka [15],

$$
\sigma=\frac{2.8 F_{f}}{\pi d^{2}}
$$

where $d$ is granule diameter. MA concentration in the granulated products were determined by following the standard procedure as proposed in US pharmacopeia. The dissolution tests for the product granules were determined using United States Pharmacopeia dissolution apparatus XXIV-Type II (paddle-37 ${ }^{\circ} \mathrm{C}$ ) (Electro Lab, Mumbai, India). The dissolution medium was a $900 \mathrm{~mL}$ phosphate buffer with $\mathrm{pH}$ 7.4. The amount of dissolved drug was determined using UV spectrophotometric method (UV 1601 A, Shimadzu, Japan) at $260 \mathrm{~nm}$. 


\section{Scanning electron microscopy}

\section{Results and Discussion}

The average size of MA particles (as received) before milling was approximately $500 \mu \mathrm{m}$ whereas the average size of MA particles after milling was about 10 to $15 \mu \mathrm{m}$. Figure 2 shows the SEM images of the core granules with addition of mefenamic acid (MA) after granulation process. Figure 2(a) shows morphology of the granules that consist of 30 wt.\% lactose and 70 wt.\% MA whereby the granulation process was conducted at ambient temperature. The same morphology was observed for other type of granules that consist of lactose, PEG and MA with 25,5 and 70 wt.\% respectively as in Figure 2 (b). The shape of the granules is spherical but it is not smooth on the surface. This might due to the size of the milled MA used in the granulation process that is slightly bigger than 5 $\mu \mathrm{m}$ whereby to have spherical and smoothness product granules, the size of the powder introduced in the fluidized bed must be less than $5 \mu \mathrm{m}[6,13,14]$.
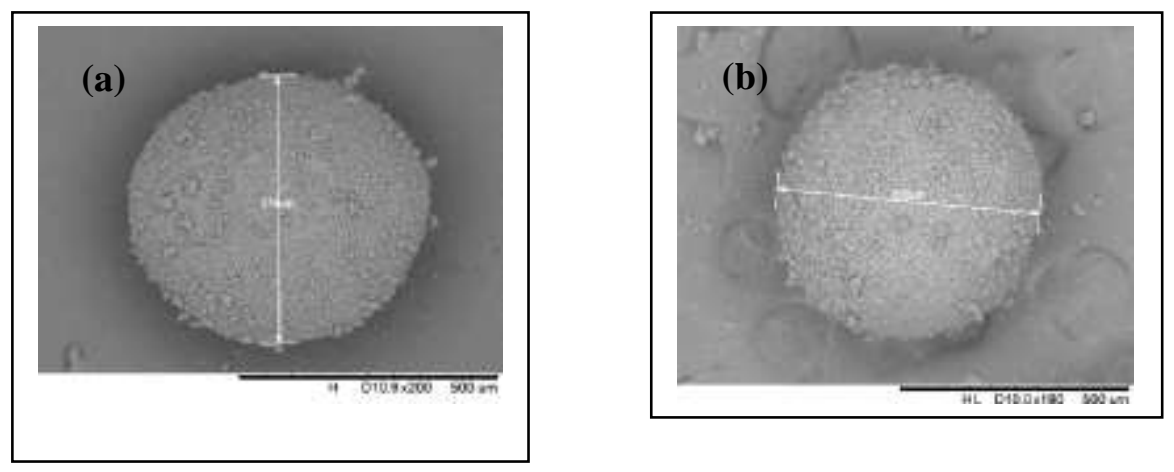

Figure 2. SEM images of (a) lactose-MA granules and (b) lactose-PEG-MA granules

\section{Granule size distribution}

Figure 3 shows the granule size distribution for all types of product granules of lactose-MA and lactose-PEG-MA. The graph shows the narrow size distribution because almost $80 \%$ of the granule size is less than $500 \mu \mathrm{m}[6,13$, 14]. According to Takano et al. [16], over $80 \%$ of the granules size must be in the range of $355 \mu \mathrm{m}$ to $1410 \mu \mathrm{m}$ for the preparation of pharmaceutical process. The sizes of the lactose-PEG-MA granules are slightly larger than the lactose-MA granules due to heating whereby PEG melted and adhered more particles on the granules.

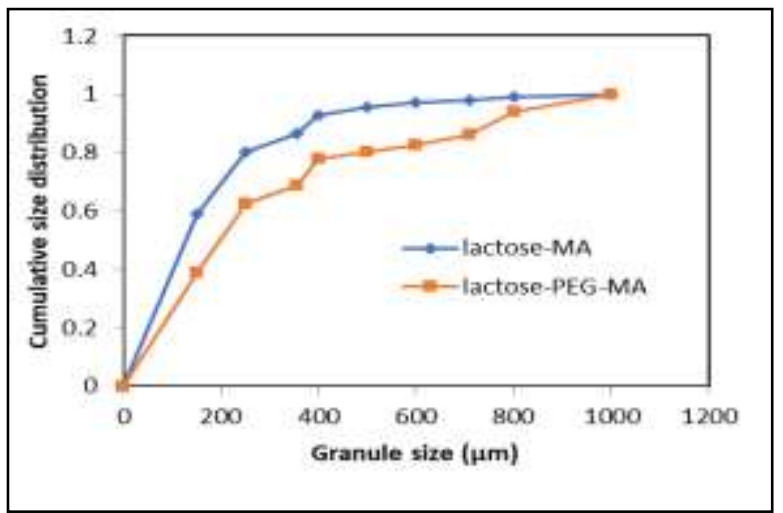

Figure 3. Granule size distributions of lactose-MA and lactose-PEG-MA

\section{Pore volume and granules density}

Table 2 shows the total pore volume and density for each size of granules for lactose-MA and lactose-PEG-MA that was measured using a pycnometer. The pore volume of granules for lactose-PEG-MA was smaller than the lactose- 
MA granules. This was due to solid bridge formation between lactose and mefenamic acid particles, when melted PEG filled and solidified in the void area inside the granules. From Table 2, it clearly shows that the pore volume for the granules increased with increasing granule size from 250 to $600 \mu \mathrm{m}$ and followed by decreasing trend for 710 and $800 \mu \mathrm{m}$. The smallest size of granules shows the lowest pore volume. The density of the lactose-MA granules was slightly higher than the lactose-PEG-MA that might due to higher amount of lactose in the lactose-MA granules although the total pore volume of the lactose-MA was higher than the lactose-PEG-MA. As the granule size increased, the porosity first increased and then decreased, and there was a maximum value of the porosity in Table 2. Summarizing Table 2, the minimum and maximum values of the porosity with increasing the granule size may be owing to the deformation created in the wet granule while melting during granulation [17]. Since all granules in PSG process normally experienced dry granulation condition, deformation $[18,20]$ was the main reason that created such pore volume, density and strength of the product granules.

Table 2. Pore volume and density for each granule size of Lactose-MA and Lactose-PEG-MA

\begin{tabular}{lcccc}
\hline \multirow{2}{*}{$\begin{array}{l}\text { Granule Size } \\
(\boldsymbol{\mu m})\end{array}$} & \multicolumn{2}{c}{ Lactose-MA } & \multicolumn{2}{c}{ Lactose-PEG-MA } \\
\cline { 2 - 5 } & $\begin{array}{c}\text { Pore Volume } \\
\left(\mathbf{c m}^{\mathbf{3}} \mathbf{g}\right)\end{array}$ & $\begin{array}{c}\text { Density } \\
\left(\mathbf{g} / \mathbf{c m}^{\mathbf{3}}\right)\end{array}$ & $\begin{array}{c}\text { Pore Volume } \\
\left(\mathbf{c m}^{\mathbf{3}} \mathbf{/ g}\right)\end{array}$ & $\begin{array}{c}\text { Density } \\
\left(\mathbf{g} / \mathbf{c m}^{\mathbf{3}}\right)\end{array}$ \\
\hline 250 & $0.2451 \pm 0.005$ & $1.3248 \pm 0.009$ & $0.2299 \pm 0.004$ & $1.3013 \pm 0.007$ \\
355 & $0.2587 \pm 0.004$ & $1.3489 \pm 0.007$ & $0.2464 \pm 0.001$ & $1.3276 \pm 0.002$ \\
400 & $0.2658 \pm 0.004$ & $1.3621 \pm 0.007$ & $0.2591 \pm 0.003$ & $1.3516 \pm 0.005$ \\
500 & $0.2743 \pm 0.234$ & $1.3761 \pm 0.013$ & $0.2721 \pm 0.003$ & $1.3740 \pm 0.006$ \\
600 & $0.2767 \pm 0.003$ & $1.3932 \pm 0.005$ & $0.2632 \pm 0.003$ & $1.3573 \pm 0.006$ \\
710 & $0.2277 \pm 0.003$ & $1.3948 \pm 0.004$ & $0.2114 \pm 0.003$ & $1.3729 \pm 0.005$ \\
800 & $0.2224 \pm 0.003$ & $1.2960 \pm 0.004$ & $0.2222 \pm 0.003$ & $1.2929 \pm 0.004$ \\
\hline
\end{tabular}

\section{Tensile strength}

Figure 4 shows the tensile strength of the product granules for different sizes. The tensile strength for lactose-PEGMA granules was higher than lactose-MA granules due to the melting of the PEG particles during heating which later formed a solid bridging inside the granule after cooling down. The tensile strength increased with decreasing granules sizes whereby small granules has less porosity, thus the number of contact points (coordination number) of primary particles can be increased by which the strength of the granules increase according to the Rumpf micromodels [19].

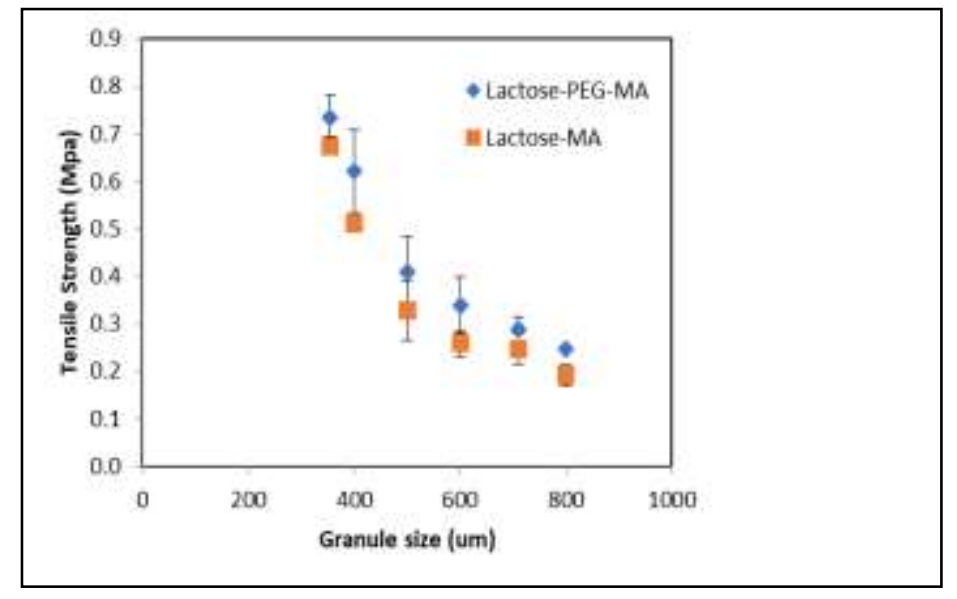

Figure 4. Tensile strength for Lactose-MA and Lactose-PEG-MA granules 


\section{Uniformity of mefenamic acid concentration}

Table 3 shows the summary of the MA concentration of the product granule for different granules sizes. The content of MA in the selected granules size was approximately similar to the feed mixture introduced before granulation process which was $70 \mathrm{wt} . \%$ for both types of granules. Although the average size of the milled MA particles was larger than other materials i.e. lactose and PEG particles, granulation using PSG can produce uniform concentration of MA regardless the size of the produced granules. As stated in [16], the uniformity of drug content in PSG granules may be related to the growth mechanism of granules in PSG as discussed by [18], where granule growth takes place by recapturing the attrited fines that are returned to the bed from the bag filter.

Table 3. Concentration of Lactose-MA and Lactose-PEG-MA in granules

\begin{tabular}{lcc}
\hline \multirow{2}{*}{$\begin{array}{l}\text { Granule Size } \\
\boldsymbol{\mu m})\end{array}$} & \multicolumn{2}{c}{ MA Concentration } \\
\cline { 2 - 3 } & Lactose-MA Granules & Lactose-PEG-MA Granules \\
\hline 355 & $61.7 \pm 18.7$ & $61.8 \pm 6.5$ \\
500 & $68.1 \pm 2.9$ & $67 \pm 1.8$ \\
800 & $68.3 \pm 7.4$ & $66.3 \pm 5.1$ \\
1000 & $82.9 \pm 3.77$ & $76.5 \pm 4.6$ \\
\hline
\end{tabular}

\section{Dissolution test}

Dissolution test for $500 \mu \mathrm{m}$ and $800 \mu \mathrm{m}$ of granule was performed with the aim to assess the effective size of granule to be used for the tablet formulation. Figure 5 shows the dissolution profile for both of the product granules. The as-received MA particles was reported to achieve less than $80 \%$ drug released at 35 minutes [21]. The granule size of $500 \mu \mathrm{m}$ indicated a comparable dissolution rate within 30 minutes i.e. as good as milled MA of average particles size of $15 \mu \mathrm{m}$ regardless the granules were formed with or without binder. The dissolution rate of $500 \mu \mathrm{m}$ was higher compared to the size $800 \mu \mathrm{m}$ for both types of granules due to higher ratio of surface area per volume. Previous works observed that the dissolution rate of MA incresead by producing smaller size of MA particles than the as received MA particles [21, 22] which emphasized on the importance of high surface per volume ratio. By referring to the same granules size, lactose-PEG-MA granules dissolved slightly better than lactose-MA granules due to existence of PEG that highly dissolve in water.

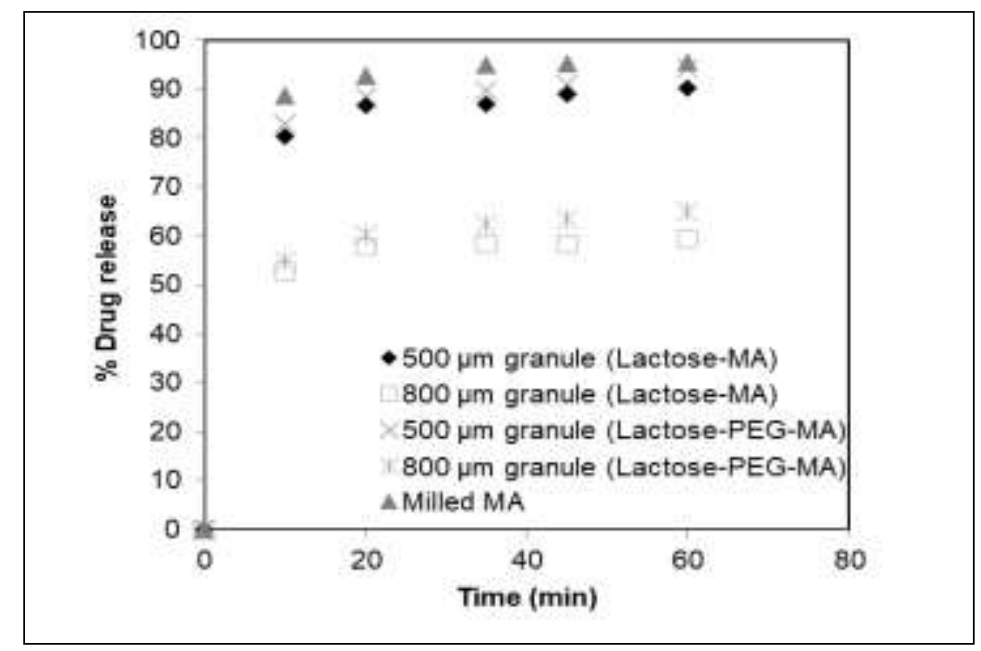

Figure 5. Dissolution test for Lactose-MA and Lactose-PEG-MA granules 


\section{Conclusion}

From the present study, both types of granules show narrow size distribution as almost $80 \%$ of the granules size was less than $500 \mu \mathrm{m}$. Tensile strength of the granules of lactose-PEG-MA was higher than the granules of lactose-MA due to heating process. The drug contents in both types of granules were uniform and almost similar to the drug content introduced before granulation which was approximately 70wt.\%. It can be concluded that by using PSG technique, granules with uniform size less than $500 \mu \mathrm{m}$, spherical shape, higher strength and high content uniformity can be achieved with and without the usage of binder. This technique is effective to be further applied for tableting formation as the drug can be dispensed effectively.

\section{Acknowledegment}

The authors would like to express their gratitude to Universiti Teknologi MARA (UiTM) Shah Alam, Malaysia for funding this work. This study was supported by Research Entity Initiative grant 600-RMI/DANA 5/3/REI (2/2013) from UiTM, Fundamental Research Grant Scheme (FRGS) 600-RMI/ST/FRGS 5/3/Fst (111/2010) and Race Acculturation Colloborative Efforts grant 600-RMI/RACE 16/6/2(6/2012) from Ministry of Education Malaysia.

\section{References}

1. Jivraj, M., Martini, L. G. and Thomson, C.M. (2000). An overview of the different excipients useful for the direct compression of tablets. Pharmaceutical Science and Technology Today, 3: 58-63.

2. Yang, J., Sliva, A., Banerjee, A., Dave, R. and Pfeffer, R. (2005). Dry particle coating for improving the flowability of cohesive powders. Powder Technology, 158: 21-33.

3. Martindale (1998). The extra pharmacopeia. The Pharmaceutical Press, London, $31^{\text {th }}$ edition: pp. 58-59.

4. Hezave, A. Z., Khademi, M. H. and Esmaelizadeh, F. (2012). Measurement and modelling of mefenamic acid solubility in supercritical carbon dioxide. Fluid Phase Equilibria, 313: 140-147.

5. James E. F. R. and Anne B. P. (1982). The extra pharmacopeia. The Pharmaceutical Press, London, 28 ${ }^{\text {th }}$ edition: pp. 262-263.

6. Abu Bakar, N. F., Mujumdar, A., Urabe, S., Takano, K., Nishii, K. and Horio, M. (2007). Improvement of sticking tendency of granules during tabletting process by pressure swing granulation. Powder Technology, 176: 137-147.

7. Abdel-Hamid, S., Alshihabi, F. and Betz, G. (2011). Investigating the effect of particle size and shape on high speed tabletting through radial die-wall pressure monitoring. International Journal of Pharmaceutics, 413: 29-35.

8. Leuenberger, H., Puchkov, M., Krausbauer, E. and Betz, G. (2009). Manufacturing pharmaceutical granules: is the granulation end-point a myth?. Powder Technology, 189: 141-148.

9. Gentis, N. D. and Betz, G. (2012). Compressibility of binary powder formulations: Investigation and evaluation with compaction equations. Journal of Pharmaceutical Sciences, 101: 777-793.

10. Siiriä, S. M, Antikainen, O., Heinämäki. J. and Yliruusi, J. (2011). 3D simulation of internal tablet strength during tabletin. AAPS PharmSciTech ¿12: 593-603.

11. Lin, X., Chyi, C. W., Ruan, K. F., Feng, Y. and Heng, P. W. (2011). Development of potential novel cushioning agents for the compaction of coated multi-particulates by co-processing micronized lactose with polymers. Europe Journal Pharmacy Biopharm, 79: 406-415.

12. Adam, A., Schrimpl, L. and Schmidt, P. C. (2000). Some physicochemical properties of mefenamic acid. Drug Development and Industrial Pharmacy, 26(5): 477-487.

13. Takano, K., Nishii, K., Mukoyama, A., Iwadate, Y., Kamiya, H. and Horio, M. (2002). Binderless granulation of pharmaceutical lactose powders. Powder Technology, 122: 212-221.

14. Nishii, K., Itoh, Y., Kawakami, N. and Horio, M. (1993). Pressure swing granulation, a novel binderless granulation by cyclic fluidization and gas flow compaction. Powder Technology, 74: 1-6.

15. Hiramatsu, Y. and Oka, Y. (1966). Determination of the tensile strength of rock by a compression test of an irregular test piece. International Journal of Rock Mechanics and Mining Science, 3: 89-90.

16. Takano, K., Maruyama, N., Mukoyama, A., Nishii, K., Kamiya, H. and Horio, M. (2003). Fluidized bed binderless granulation of hydrophobic drugs with fine lactose powder. Advanced Powder Technology, 14(3): 369-381.

17. Shu-hua, D., Feng-man, S. and Ai-bing, Y. (2008). Granule size distribution and porosity of granule packing. Journal of Iron and Steel Research, 15(5): 1-5. 
18. Abu Bakar, N. F., Anzai, R. and Horio, M. (2009). Direct measurement of particle-particle interaction using micro particle interaction analyzer (MPIA). Advanced Powder Technology, 20(5): 455-463

19. Horio, M., Mukouyama, A., Maruyama, M., Takano, K. and Nishii, K. (2001). The mechanism of fluidized bed dry granulation of fine powders. Fluidization, 10: 485-491.

20. Abu Bakar, N. F., Anzai, R. and Horio, M. (2013). Microscopic evaluation of binderless granulation in a pressure swing granulation fluidized bed. Chemical Engineering Science, 98: 51-58/

21. Zolkepali, N. K., Abu bakar, N. F., Naim, M. N., Anuar, N., Kamalul Aripin, N. F., Abu Bakar, M. R., Lenggoro, I. W. and Kamiya, H. (2016). Formation of fine and encapsulated mefenamic acid form I particles for dissolution improvement via electrospray method. Particulate Science and Technology, 36(3): 298-307.

22. Zolkepali, N. K., Abu Bakar, N. F., Naim, M. N., Anuar, N. and Abu Bakar, M. R. (2014). Nanoparticle preparation of mefenamic acid by electrospray drying. AIP Conference Proceedings, 1586: 113-118 